\title{
Diagnosis, treatment, and rehabilitation of stress fractures in the lower extremity in runners
}

This article was published in the following Dove Press journal:

Open Access Journal of Sports Medicine

27 March 2015

Number of times this article has been viewed

\author{
Leamor Kahanov' \\ Lindsey E Eberman ${ }^{2}$ \\ Kenneth E Games ${ }^{2}$ \\ Mitch Wasik ${ }^{2}$ \\ 'College of Health Science, \\ Misericordia University, Dallas, \\ PA, USA; ${ }^{2}$ Department of Applied \\ Medicine and Rehabilitation, Indiana \\ State University, Terre Haute, IN, USA
}

\begin{abstract}
Stress fractures account for between 1\% and 20\% of athletic injuries, with $80 \%$ of stress fractures in the lower extremity. Stress fractures of the lower extremity are common injuries among individuals who participate in endurance, high load-bearing activities such as running, military and aerobic exercise and therefore require practitioner expertise in diagnosis and management. Accurate diagnosis for stress fractures is dependent on the anatomical area. Anatomical regions such as the pelvis, sacrum, and metatarsals offer challenges due to difficulty differentiating pathologies with common symptoms. Special tests and treatment regimes, however, are similar among most stress fractures with resolution between 4 weeks to a year. The most difficult aspect of stress fracture treatment entails mitigating internal and external risk factors. Practitioners should address ongoing risk factors to minimize recurrence.

Keywords: medial tibial stress syndrome, stress injury, nonunion stress fracture
\end{abstract}

\section{Introduction}

Stress fractures of the lower extremity are common injuries among individuals who participate in endurance, high load-bearing activities such as running, military and aerobic exercise and therefore require practitioner expertise in diagnosis and management. ${ }^{1-20}$ Stress fractures in the lower extremity account for $80 \%-90 \%$ of all stress fractures, representing between $0.7 \%$ and $20 \%$ of all sports medicine injuries. ${ }^{3,6,9,16}$ Specifically, stress fracture incidence in runners approaches $16 \%$ of all injuries. ${ }^{3}$ The most common stress fractures occur in the tibia (23.6\%) but also develop in the tarsal navicular (17.6\%), metatarsals (16.2\%), femur (6.6\%), and pelvis (1.6\%). ${ }^{1,2,7,13-15,17-19}$ Stress fractures occur due to overuse and/or overload, when the rate of stress-induced microfractures exceeds the rate at which bone repairs, requiring the recognition and management of risk factors. ${ }^{12}$

Accurate diagnosis for stress fractures is dependent on the anatomical area. Regardless, early recognition is the optimal goal to minimize the potential for microfractures to become macrofractures. Anatomical regions such as the pelvis, sacrum, and metatarsals offer challenges due to difficulty differentiating pathologies with common symptoms. Special tests and treatment regimes, however, are similar among most stress fractures with resolution between 4 weeks to a year. We present evidence-based concepts regarding lower extremity stress fractures to provide practitioners with an updated overview of diagnosis, treatment, and rehabilitation.

\section{Diagnosis}

Clinical treatment decisions based on history, clinical examination, and special tests present similarly for most stress fractures (Table 1). Stress fracture injuries 
Table I Stress fracture symptoms and differential diagnosis in most common anatomical sites

\begin{tabular}{|c|c|c|c|}
\hline $\begin{array}{l}\text { Stress fracture } \\
\text { location }\end{array}$ & Differential diagnosis & History and physical evaluation & $\begin{array}{l}\text { Special } \\
\text { considerations } \mathbf{s}^{+*}\end{array}$ \\
\hline $\begin{array}{l}\text { Great toe } \\
\text { sesamoid }\end{array}$ & $\begin{array}{l}\text { - Sesamoiditis } \\
\text { - Avascular necrosis } \\
\text { - Synchondrosis } \\
\text { - Partite sesamoid } \\
\text { - Osteomyelitis } \\
\text { - Bursitis }\end{array}$ & $\begin{array}{l}\text { - Focal point tenderness and swelling } \\
\text { - Pain on dorsiflexion } \\
\text { - Pain during weight bearing and push off } \\
\text { - Increasing pain with activity }\end{array}$ & $\begin{array}{l}\text { Surgical management } \\
\text { suggested if conservative } \\
\text { treatment unsuccessful }\end{array}$ \\
\hline Metatarsals & $\begin{array}{l}\text { - Strain } \\
\text { - Plantar fasciitis } \\
\text { - Morton's neuroma } \\
\text { - Metatarsalgia }\end{array}$ & $\begin{array}{l}\text { - Pain during weight bearing } \\
\text { - Focal swelling } \\
\text { - Focal tenderness }\end{array}$ & $\begin{array}{l}\text { Conservative management } \\
\text { Ist through 4th metatarsal } \\
\text { Surgical management } \\
5 \text { th metatarsal }\end{array}$ \\
\hline Tibia - medial & $\begin{array}{l}\text { - Medial tibial stress syndrome } \\
\text { - Meniscal pathology (medial tibial condyle) } \\
\text { - Ligamentous injury (medial malleoli, tibial } \\
\text { condyle) } \\
\text { - Malignant tumor (medial tibial condyle) }\end{array}$ & $\begin{array}{l}\text { - Focal pain during weight-bearing/or activity } \\
\text { along tibial shaft } \\
\text { - Pain with percussion }\end{array}$ & Conservative management \\
\hline Tibia - anterior & $\begin{array}{l}\text { - Compartment syndrome } \\
\text { - Tendinopathy }\end{array}$ & $\begin{array}{l}\text { - Focal pain during weight-bearing/or activity } \\
\text { along tibial shaft } \\
\text { - Pain with percussion }\end{array}$ & $\begin{array}{l}\text { Surgical when conservative } \\
\text { treatment fails - } \\
\text { intramedullary rodding }\end{array}$ \\
\hline Fibula & $\begin{array}{l}\text { - Meniscal injuries } \\
\text { - Lateral ligament sprains }\end{array}$ & $\begin{array}{l}\text { - Focal pain and tenderness } \\
\text { - Referred knee pain }\end{array}$ & Conservative management \\
\hline $\begin{array}{l}\text { Femur/femoral } \\
\text { shaft }\end{array}$ & $\begin{array}{l}\text { - Rectus femoris strain } \\
\text { - Adductor strain }\end{array}$ & $\begin{array}{l}\text { - Dependent on location of injury } \\
\text { o Groin } \\
\text { o Anterior thigh } \\
\text { o Gluteal } \\
\text { o Knee } \\
\text { - Activity related pain } \\
\text { - Hip pain at end ranges of motion } \\
\text { - Pain with one leg hop } \\
\text { - No pain on palpation } \\
\text { - Night pain may be present }\end{array}$ & Conservative management \\
\hline Femoral neck & $\begin{array}{l}\text { - Trochanteric bursitis } \\
\text { - Strain in hip musculature }\end{array}$ & $\begin{array}{l}\text { - Anterior groin pain } \\
\text { - Increasing pain with activity } \\
\text { - Pain with straight leg raise } \\
\text { - Pain with log roll } \\
\text { - Pain with one leg hop }\end{array}$ & $\begin{array}{l}\text { Internal fixation } \\
\text { recommended in stress } \\
\text { fractures on the superior } \\
\text { neck }\end{array}$ \\
\hline $\begin{array}{l}\text { Pelvis } \\
\text { (pubic rami) }\end{array}$ & $\begin{array}{l}\text { - Strain of adductors } \\
\text { - Bursitis }\end{array}$ & $\begin{array}{l}\text { - Groin, buttock, or thigh pain } \\
\text { - Focal tenderness } \\
\text { - Pain with single leg stance on affected side } \\
\text { - Positive hop test } \\
\text { - Point tender (may be extreme) on pubic rami }\end{array}$ & Conservative management \\
\hline Sacrum & $\begin{array}{l}\text { - Sciatica } \\
\text { - Disk pathology } \\
\text { - Sacroiliac joint pathology } \\
\text { - Strain of gluteus maximus } \\
\text { - Strain deep external rotators or piriformis } \\
\text { - Strain hamstring }\end{array}$ & $\begin{array}{l}\text { - SI and/or buttock pain during palpation and } \\
\text { load bearing activity } \\
\text { - Low back pain } \\
\text { - Radiculopathy } \\
\text { - Additional physical examinations are } \\
\text { typically unremarkable }\end{array}$ & \\
\hline
\end{tabular}

Notes: ${ }^{+}$MRI is considered the most sensitive imaging method and is used for diagnosis; $*_{\text {in }}$ general, the treatment regime (conservative management) follows the two-phased approach, and this column represents rehabilitation/treatment techniques that augment the standard stress fracture approach.

Abbreviations: MRI, magnetic resonance imaging; SI, sacroiliac.

most often evolve with an insidious onset that typically occurs at the end of physical activity with a focal point of tenderness. ${ }^{3,7}$ Athletes may identify a history that articulates the progression of stress fracture from pain with activity to persistent pain during activity and finally during daily ambulation. The history may include a recent change or increase in physical activity or repetitive exercise with minimal recovery time. ${ }^{6,21-23}$ Physical examination typically identifies tenderness localized over the involved bony area, both with and without localized swelling. Special tests for 
specific anatomical areas of stress fracture include the hop test, fulcrum test, and hyperextension test. ${ }^{7}$

Currently, an overall classification system to grade stress fractures is lacking ${ }^{24,25}$ although Fredericson et $\mathrm{al}^{7}$ have reported a grading system for tibial stress fractures with magnetic resonance imaging (MRI) (Table 2). Thus, the closest grading, prognosis, and treatment system in the literature to classify stress fractures is high or low risk (Table 2). ${ }^{1,2,16}$ High risk fractures typically require surgical repair based on a likelihood that the stress fracture will progress to a complete fracture, delayed union or nonunion, or requires assisted/nonweight-bearing. Low risk stress fractures generally respond to conservative treatment. Assessment of low and high risk stress fractures should not only include history and physical evaluation, but also imaging to identify classification and determine treatment and rehabilitation parameters.

Imaging is adjunctive to patient history and physical examination (Table 3). ${ }^{16}$ Regardless of stress fracture location, MRI is currently the gold standard, largely due to the instrument's ability to display both soft tissue and bone edema. ${ }^{1}$ One of the earliest signs of stress fracture is bony edema, which is not easily visible on standard radiographic imaging. ${ }^{5}$ Radiographic films may provide a supplement to clinical history by exhibiting information related to periosteal bone formation, cortical margin, and fracture line, all of which may not be visible within the first 2 weeks of symptomatic complaints. ${ }^{5}$ Radiographs lack the ability to determine acute stress fractures since it may take 3 weeks for cortical irregularities and periosteal reactions to become evident, therefore, other imaging techniques are suggested. ${ }^{16,26}$ Likewise, computer tomography scans have been identified as useful in the diagnosis of stress fractures but lack the sensitivity of MRIs to provide concurrent evaluation of soft tissue ${ }^{16}$ Bone scans (scintigraphy) are also a highly sensitive modality in the diagnosis of stress fractures yet are seldom used due to radiation exposure and the advent of MRI sensitivity in diagnosing stress fractures. ${ }^{26,27}$ Although literature supporting the use of ultrasonography is limited, potential exists for future uses. Currently, MRI is the most sensitive and specific diagnostic imaging tool.

\section{First metatarsal and sesamoid}

Great toe sesamoid stress fractures account for approximately $0.4 \%$ of all running injuries. ${ }^{28}$ Differential diagnosis of sesamoid stress fractures with sesamoiditis, avascular necrosis and partite sesamoid bones, osteomyelitis and bursitis between the sesamoid, and flexor hallucis brevis tendon may be complicated or delayed, as all have similar symptoms to stress fractures. ${ }^{28,29}$ Signs and symptoms are identical to general stress fracture assessment findings, including normal plain films and MRI identification of focal inflammation. Stress fractures of sesamoids are more common in one bone compared to sesamoiditis, bursitis, tendinosis, and tenosynovitis, which more commonly involve both sesamoids. ${ }^{28,30,31}$

\section{Metatarsal}

Metatarsal stress fractures typically occur in the second and third metatarsal shafts, which overall, constitutes $20 \%$ of lower extremity stress fractures. ${ }^{2,32}$ Although fifth metatarsal stress fractures occur, they are rare, and athletes typically report a recent history of trauma. ${ }^{9}$ Stress fractures of the metatarsals

Table 2 Low and high risk stress fracture classification and Fredericson tibial MRI classification

\begin{tabular}{|c|c|c|}
\hline Low risk classification & High risk classification & $\begin{array}{l}\text { Fredericson classification for tibial } \\
\text { stress fractures }\end{array}$ \\
\hline $\begin{array}{l}\text { - Heal with conservative treatment } \\
\text { - Nonsurgical management } \\
\text { - Compression stress fractures } \\
\text { - Typically includes } \\
\text { o Femoral shaft } \\
\text { o Medial tibia } \\
\text { o Fibula } \\
\text { o Calcaneus } \\
\text { o Ist-4th metatarsals }\end{array}$ & $\begin{array}{l}\text { - Risk for complete fracture } \\
\text { - Risk for nonunion } \\
\text { - Delayed union } \\
\text { - Typically requires surgical intervention } \\
\text { - Requires nonweight-bearing or } \\
\text { assisted weight-bearing } \\
\text { - Tension stress fractures } \\
\text { - Typically includes } \\
\text { o 5th metatarsal } \\
\text { o Anterior tibia } \\
\text { o Tarsal navicular } \\
\text { o Femoral neck } \\
\text { o Patella } \\
\text { o Ist metatarsal sesamoid }\end{array}$ & $\begin{array}{l}\text { - Grade I: periosteal edema only } \\
\text { - Grade 2: bone marrow edema visible on } \\
\text { T2-weighted images } \\
\text { - Grade 3: bone marrow edema visible on } \\
\text { both TI-weighted and T2-weighted images } \\
\text { - Grade 4: intracortical signal abnormalities }\end{array}$ \\
\hline
\end{tabular}

Note: Data from Kaeding et al, ${ }^{6}$ and Fredericson et al. ${ }^{36}$

Abbreviation: MRI, magnetic resonance imaging. 
Table 3 Imaging techniques for stress fractures

\begin{tabular}{|c|c|c|}
\hline Imaging modality & Advantages & Disadvantages \\
\hline \multirow[t]{2}{*}{ Computer tomography $17,45,48$} & Differentiates malignancies, stress & Lower sensitivity \\
\hline & fractures, and stress reactions & High radiation \\
\hline \multirow[t]{2}{*}{ Magnetic resonance imaging $7,13,26,28,30,44,46,65,66$, I I 2} & High sensitivity $(80 \%-100 \%)$ & High cost \\
\hline & High specificity (100\%) & Access \\
\hline \multirow[t]{3}{*}{ Radiographs $s^{5,15,16,26,38,45}$} & Access & Poor sensitivity (10\%) within first $2-3$ weeks \\
\hline & Low radiation & \\
\hline & Low cost & \\
\hline \multirow[t]{3}{*}{ Scintigraphy $6,26,27,107,112$} & High sensitivity (74\%-100\%) & False positives in cases of tumor or infection \\
\hline & Moderate specificity (68\%) & Radiation exposure \\
\hline & Low cost & \\
\hline \multirow[t]{2}{*}{ Ultrasonography ${ }^{17,106}$} & No radiation & Limited data exists on specificity (75\%) \\
\hline & Low cost & sensitivity (83\%) \\
\hline
\end{tabular}

may be due to fatigue of plantar flexion musculature during prolonged or strenuous running, which decreases dissipation forces and increases stress on the metatarsals thereby contributing to stress fractures. ${ }^{32,33}$ An understanding of the etiology may enhance prevention strategies to reduce risk fractures through training modifications. Athletes typically present with pain upon weight-bearing, focal swelling, and point tenderness. A history of change in terrain, training regime, and/or recent trauma is standard.

Distal fourth metatarsal fractures are more common than proximal fourth metatarsal or proximal fifth metatarsal stress fractures. These fractures usually incur a prolonged healing rate with athletes experiencing symptoms beyond 3 months of rest and immobilization. ${ }^{34}$ Delayed union or nonunion is more common in metatarsal stress fractures and may require surgical intervention with intramedullary fixation that also addresses torsional stresses. ${ }^{35-37}$

\section{Tarsal bones}

Stress fractures of the tarsal bones, particularly the navicular, constitute approximately $20 \%$ of stress fractures in runners; although, the majority are identified in sprinters. ${ }^{3,38}$ The navicular is vulnerable to stress fractures due to limited vascularity, which also diminishes healing. Diagnosis is difficult due to the location and diffuse midfoot pain that radiates to the medial arch and begins insidiously and increases with activity. ${ }^{2,16,29}$ Pain and tenderness is evident on the dorsal navicular upon palpation. The cuboid, however, is more difficult to diagnose, perhaps due to the rarity or differential diagnosis of peroneal tendon pathology. ${ }^{39-41}$

Talar stress fractures reveal themselves with pain along the talar dome. MRI is the best diagnostic tool for an acute and/or recent talar stress fracture. ${ }^{42}$ Current literature indicates that nonsurgical treatment with nonweight bearing immobilization for 6 weeks is comparable to surgery yet avoids potential surgical complications. ${ }^{43}$

\section{Fibular}

Fibular stress fractures account for $7 \%-12 \%$ of all stress fractures. ${ }^{44-46}$ The most common site for stress fractures occurs at the distal fibula, with proximal stress fractures more common to jumpers rather than distance runners. ${ }^{3,9,15,29,47}$ The stress fractures present with local pain and tenderness over the fibula, with occasional referred knee pain. . $^{3,9,15,29,47}$ Signs and symptoms specific to fibular stress fractures are typical with a history of progressive pain during activity, focal tenderness, and localized swelling. ${ }^{29}$ Imaging findings are similar to other stress fractures, with MRI evidence being the most sensitive. ${ }^{43-48}$

\section{Tibia}

The tibia is the most common site of stress reactions and stress fractures in runner athletes..$^{15,38,48}$ The majority of stress fractures are low risk and located posteriomedially. ${ }^{16}$ Anterior medial stress fractures are less common yet considered high risk due to the high incidence of nonunion. ${ }^{16,48-51}$ Signs and symptoms generally include pain and tenderness on the medial shaft of the tibia which increases with exercise. ${ }^{16,29}$ Athletes with smaller tibial cross sectional dimensions are at a greater risk for the development of tibial stress, yet this might be difficult to delineate prior to injury. ${ }^{47}$ Much like the majority of stress fractures, plain radiographs are seldom abnormal, with MRI constituting the most sensitive and specific findings. ${ }^{52}$

Diagnosis of stress fractures at the medial tibial condyle and medial malleolus may be more difficult to diagnose since they mimic meniscal tears, ligamentous injuries, and cartilage pathologies. ${ }^{29}$ The large amount of bone marrow indicated on MRI with these stress fractures may be mistaken 
for malignant tumors, often resulting in unneeded biopsy. ${ }^{26}$ Thus, a thorough history including running overload activity coupled with localized tenderness and swelling and a positive MRI should be investigated extensively to minimize inaccurate diagnoses.

\section{Patella}

Case studies have identified longitudinal and transverse patella stress fractures. ${ }^{53}$ Perhaps due to the infrequent nature of patellar stress fractures, or that differential diagnosis is more synonymous with alternative diagnosis of chronic symptomatic bipartite patellae and Sinding-Larsen-Johansson disease, patellar stress fractures are difficult to assess. Eliminating the existence of these other conditions is both necessary and more effective in determining a diagnosis of patellar stress fracture. ${ }^{16,21,52}$

\section{Femur}

Femoral stress fractures typically present with hip, groin, gluteal, thigh, or knee pain, depending on the location. ${ }^{53,54}$ Likewise, athletes may identify vague thigh pain accompanied with diffuse tenderness, particularly for femoral neck stress fractures. ${ }^{29}$ Femoral stress fractures have a high morbidity rate due to high compression and tensile force loads greater than the body weight. ${ }^{56,57}$ The morbidity rate ranges from $20 \%-86 \%$ in the literature from complete fractures, malunion, impingement, nonunion, avascular necrosis, and arthritic changes. ${ }^{27,57,58}$ The most common stress fracture site is of the femoral shaft, followed by the lesser trochanter and intertrochanteric region. ${ }^{54}$ Regardless of region, athletes typically present with pain during activity which may be reproducible on passive range of motion, specifically internal rotation and when asked to hop on the affected limb. Femoral stress fractures have proven to be elusive with the average delay in diagnosis around 14 weeks. ${ }^{57,59}$ Plain radiographs are typically normal and again, MRI is the best diagnostic test to depict stress fractures of the femur. ${ }^{59}$

Treatment of femoral stress fractures is dependent on the location and any displacement. Displacement is the primary indicator for prognosis with $60 \%$ displacement the marker for reduction of activity level in sport with potential avascular necrosis. ${ }^{57}$ The majority of femoral stress fractures that lack displacement respond to conservative treatment within 8-14 weeks. ${ }^{60}$ Femoral neck fractures on the superior aspect tend to be tension fractures with a greater risk for displacement; management for these includes internal fixation. ${ }^{61}$ Continued follow-up with repeated imaging is recommended for conservative treatment to verify resolution and minimize progression to displacement, which increases complications. ${ }^{16}$

\section{Pelvis}

Pelvic stress fractures represent approximately $1 \%-2 \%$ of all stress fractures. ${ }^{22,29,62}$ Stress fractures at the pubic rami near the symphysis are the most common pelvic stress fractures among runner athletes. ${ }^{59}$ Symptoms include low back, buttock, groin, and thigh pain during activity, which may become debilitating in progressed stress fractures..$^{22,29,62-66}$ Pain upon deep palpation of the pubic ramus may assist in differentiation between affected and an overlying soft-tissue pathology. ${ }^{63}$ Most pelvic stress fractures are nondisplaced, requiring an MRI for diagnosis. Return to participation ranges from 7-12 weeks with conservative treatment. ${ }^{22,29,62-66}$

\section{Sacrum}

Sacral stress fractures are uncommon injuries characterized by low back and buttocks pain. 1,2,7,9,11-17,19 Symptoms include low back and/or buttock pain typically exacerbated by single leg hopping. ${ }^{1-21}$ Sacral stress fractures are difficult to diagnose given the symptoms are representative of several injuries including low back, disk disease, sciatica, sacroiliac joint pathology, and piriformis syndrome. Scintigraphy or MRI are useful in diagnosis when coupled with a history of load-bearing endurance activities, sacral iliac joint and low back tenderness, and a positive hop test. ${ }^{66}$ Plain radiographs may assist in eliminating other pathologies but are not typically useful in diagnosing stress fractures. ${ }^{66}$ Participants typically return to athletic participation within 4 to 6 weeks with management similar to other stress fractures such as removal from activity and reduced load-bearing activities associated with running or jogging. ${ }^{11}$

\section{Treatment and rehabilitation}

Treatment, whether conservative or surgical, should be based on recognizing and modifying risk factors that may be intrinsic or extrinsic factors. Intrinsic factors such as race (Caucasian), ${ }^{67-71}$ maturity, ${ }^{67-71}$ nutritional and menstrual irregularities in women, ${ }^{68,70,72,73}$ smoking, ${ }^{74-76}$ and sport (distance/endurance runners) constitute factors that impact the occurrence of stress fractures. Modifying or minimizing the risk factors may reduce reccurrence and enhance the rehabilitation plan.

The vast majority of stress fractures heal within 8 weeks through conservative treatment (Table 4); however, a small percentage may require surgical intervention due to non- or 
Table 4 Return to weight bearing activities

\begin{tabular}{lll}
\hline Stress fracture & High risk/low risk & $\begin{array}{l}\text { Average time to } \\
\text { weight bearing } \\
\text { activities }\end{array}$ \\
\hline Sesamoid & High risk & 6 weeks \\
Metatarsal & Low risk & $4-6$ weeks \\
Anterior tibia & High risk & $6-8$ weeks \\
Posteromedial tibia & Low risk (cortical break) & $8-12$ weeks \\
& Low risk (minor injury) & $<3$ weeks \\
Fibula & Low risk & $2-4$ weeks \\
Femoral neck & High risk & $4-6$ weeks \\
Femoral shaft & Low risk & $6-8$ weeks \\
Sacrum/pelvis & Low risk & $7-12$ weeks \\
\hline
\end{tabular}

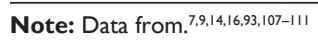

delayed-union. ${ }^{18} \mathrm{~A}$ two-phased protocol for rehabilitation for the runner with lower extremity stress fractures is generally accepted as a suitable trajectory for return to participation. ${ }^{7,9,14}$ The first phase of a conservative rehabilitation protocol includes rest of the anatomical site, maintenance of aerobic fitness, physical therapy modalities, and oral analgesics ${ }^{3,77}$ other than nonsteroidal anti-inflammatory drugs, which potentially slow bone healing. ${ }^{78}$ Phase one should include weight-bearing as tolerated and ambulation modification if needed, yet running should be avoided. Likewise, minimal-impact activities to maintain cardiovascular fitness should be initiated, such as cycling, pool running, antigravity treadmill running, cycling, and swimming. The second phase of stress fracture rehabilitation should begin 2 weeks after the athlete is pain free with ambulation and cross-training and focus on progressive return to full impact activities such as running. ${ }^{9,14}$ Rehabilitation during the second phase should focus on muscular endurance training, ${ }^{7,90}$ core and pelvic girdle stability, ${ }^{7,83,84-90}$ balance/proprioception training, ${ }^{7}$ flexibility, ${ }^{7,14,80}$ and gait retraining ${ }^{83,86-90}$ when appropriate. Muscular endurance and stability should focus on whole body training two to three times per week, with the loading variable based on experience. ${ }^{91,92}$ The novice may incur light loads for ten to 15 repetitions while advanced athletes may assume heavier loads of ten to 25 repetitions. ${ }^{91-93}$ Once the athlete is pain-free for 10 to 14 days, with resolution of focal point tenderness, phase two should begin. Phase two includes the initiation of a running progression. Runners should gradually increase to preinjury level over 3 to 6 weeks under medical supervision dictated by pain reccurrence. ${ }^{79,81,82}$

Return to sport activity should coincide with pain free weight-bearing. The average time to return is based upon injury classification (high and low grade) (Table 4). These clinical practice guidelines are based on MRI observations associated with a sufficient amount of healing. ${ }^{78,79,81}$ A progressive running plan coupled with a comprehensive rehabilitation protocol are effective for returning individuals to running. ${ }^{7,87,94,95}$ Return to running activity should begin with between $30 \%$ and $50 \%$ of the pre-injury (reference normed to the individual) and progress using the $10 \%$ rule. The $10 \%$ rule increases running mileage and intensity no more than $10 \%$ per week once weight bearing is approved (Table 4). ${ }^{7,87,94,95}$ Although general guidelines are provided for return to activity, practitioners should monitor runners based on pain, range of motion, and signs and symptoms, with referral for additional imaging with return of symptoms. ${ }^{14}$ Likewise, any return to participation should include modifications of potential risk factors such as biomechanical, nutrition, training, and equipment factors. Although the identification of risk factors are noted in the literature, ${ }^{7,11,29,71,73,74}$ the usefulness of mitigating risk factors in the prevention of stress fractures is lacking, and thus recommendations for specific regimens are absent. ${ }^{17}$ Individual assessment and reassessment to minimize the injury is therefore suggested. ${ }^{17}$

High risk stress fractures in grade 1 or 2 categories (Table 2) typically resolve nonsurgically with immobilization and weight bearing modification, and return to activity only after the fracture has achieved complete healing is essential to avoid full fracture. ${ }^{1,24}$ The selection of surgery as a treatment choice should be a decision between the athlete and sports medicine professional, based on sport, fracture site, grade of fracture, and competitive participation requirements. ${ }^{3}$

Average return to participation timelines based on low and high risk categories indicate that low risk, low grade stress fractures average 61 days to return, followed by low risk, high grade at 153 days; high risk, low grade at 135 days; and high risk, high grade at 131 days. ${ }^{78,82}$ Consequently the most precarious stress fractures for return to participation are the low risk, high grade stress fractures, particularly where athletes may interpret the lack of risk for full fracture as a license to return prematurely. Practitioners must maintain cardiovascular fitness and creativity in rehabilitation and perhaps employ a sport psychologist to ensure athletes continue to adhere to the rehabilitation regime and minimize the risk of early return.

\section{Modifying risk factors}

The management of risk factors such as biomechanical stresses, nutrition, and overtraining may be the key to long term and successful treatment. ${ }^{29}$ External risk factors such as training regimes and equipment may play a role in risk management of stress fractures. Higher mileage is associated with an increased risk for fractures; however, a difficulty in providing therapeutic alternatives exists. ${ }^{8,75,96-98}$ Bone recovery may be a greater risk factor in the development and treatment of stress 
fractures; therefore, the implementation of recovery periods with alternate training (eg, water running, cross-training) benefits recovery time without decreasing fitness levels..$^{71,75}$

Terrain and equipment may contribute to risk factors and, therefore, treatment considerations. Runners who change terrain or run hilly landscapes are more likely to incur stress fractures. ${ }^{67,99}$ Thus, limiting hills and multiple terrains during recovery and for future training in individuals who are susceptible for stress fractures is pertinent. The use of orthotics may be effective for some athletes in reducing lower extremity stressors by increasing shock absorption. ${ }^{100}$ In addition, decreases in shoe shock absorption can be avoided by changing shoes every 6 months or 300-500 miles to limit overuse injuries. ${ }^{9,69}$

Intrinsic factors such as nutrition and biomechanical variances is controversial in the literature related to the prevention of stress factors. ${ }^{17,22,98,100}$ Current literature indicates that high levels of calcium (1,500-2,000 mg) and vitamin D supplementation (800-1000 IU) may be a component of stress fracture prevention; however, the literature is conflict-

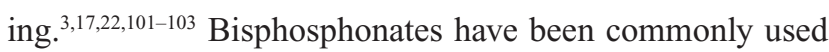
to treat stress fractures, yet some concerns exist with the potential for abnormal long term bone deposition and a lack of Food and Drug Administration approval for this intervention. ${ }^{50,68,104,105}$ Athletes should be assessed for deficiencies, eating disorders, and medication-induced deficiencies prior to added supplementation. ${ }^{3,106}$

Biomechanical factors such as calf girth, muscle mass, genu valgus greater than $15 \%$, excessive hip adduction, rear foot eversion, and female athlete triad (amenorrhea, osteoporosis and eating disorder), may predispose athletes to stress fractures. ${ }^{47,67,91,98}$ Likewise, a low bone mass density, menstrual irregularities, and energy deficiency may contribute and should therefore be assessed in individuals with stress fractures to provide appropriate treatment parameters. ${ }^{106}$

\section{Conclusion}

Diagnosis, rehabilitation, and return to running activities require similar assessment and progression for most lower extremity stress fractures. Specific special tests and differential diagnosis may vary, depending on the anatomical site of the stress fracture; regardless, prompt diagnosis is imperative in order to begin appropriate treatment plans. The most difficult aspect of stress fracture treatment entails mitigating internal and external risk factors. Practitioners should address ongoing risk factors to minimize reccurrence.

\section{Disclosure}

The authors report no conflicts of interest in this work.

\section{References}

1. Boden BP, Osbahr DC. High-risk stress fractures: evaluation and treatment. J Am Acad Ortop Surg. 2000;8(6):344-353.

2. Brukner P, Bradshaw C, Kahn KM, White S, Crossley K. Stress fractures: a review of 180 cases. Clin J Sport Med. 1996;6(2):85-89.

3. Chen YT, Tenforde AS, Fredericson M. Update on stress fractures in female athletes: epidemiology, treatment, and prevention. Curr Rev Musculoskelet Med. 2013;6(2):173-181.

4. Corrarino JE. Stress fractures in runners. Nurse Prac. 2012;37(6): 19-28.

5. Delvaux K, Lysens R. Lumbosacral pain in an athlete. Am J Phys Med Rehabil. 2001;80(5):388-391.

6. Fredericson M, Bergman AG, Hoffman KL, Dillingham MS. Tibial stress reaction in runners. Correlation of clinical symptoms and scintigraphy with a new magnetic resonance imaging grading system. Am J Sports Med. 1995;23(4):472-481.

7. Fredericson M, Jennings F, Beaulieu C, Matheson GO. Stress fracture in athletes. Top Magn Reson Imaging. 2006;17(5):309-325.

8. Gilchrist J, Jones BH, Sleet DA, Kimsey CD; CDC. Exercise-related injuries among women: strategies for prevention from civilian and military studies. MMWR Recomm Rep. 2000;49(RR-2):15-33.

9. Harrast MA, Colonno D. Stress fracture in runners. Clin Sports Med. 2010;29(3):399-416.

10. Jones BH, Cowan DN, Knapik JJ. Exercise, training and injuries. Sports Med. 1994;18(3):202-214.

11. Kahanov L, Eberman LE, Alvey T, True J, Yeargin B. Sacral stress fracture in a distance runner. J Am Osteo Assoc. 2011;111(10):585-591.

12. Kilcoyne KG, Dickens JF, Rue JP. Tibial stress fractures in an active duty population: long-term outcomes. J Surg Orth Adv. 2013;22(1): 50-53.

13. Lee CH, Huang GS, Chao KH, Jean JL, Wu SS. Surgical treatment of displaced stress fractures of the femoral neck in military recruits: a report of 42 cases. Arch Orthop Trauma Surg. 2003;123(10):527-533.

14. Liem BC, Truswell HJ, Harrast MA. Rehabilitation and return to running after lower limb stress fractures. Curr Sports Med Rep. 2013;12(3):200-207.

15. Matheson GO, Clement DB, McKenzie DC, Taunton JE, Lloyd-Smith DR, MacIntyre JG. Stress fractures in athletes. A study of 320 cases. Am J Sports Med. 1987;15(1):46-58.

16. McCormick F, Nwachukwu BU, Provencher MT. Stress fractures in runners. Clin Sports Med. 2012;31(2):291-306.

17. Patel DS, Roth M, Kapil N. Stress fractures: diagnosis, treatment, and prevention. Am Fam Phys. 2001;83(1):39-46.

18. Snyder RA, Koester MC, Dunn WR. Epidemiology of stress fractures. Clin Sports Med. 2006;25(1):37-52.

19. Tyburski MD, Saint-Phard D, Laker S, Van Dorsten B, McCarty E. Femoral stress fractures in a team of elite cross-country runners: a retrospective study of related factors. Med Sci Sport Exer. 2006;38(5):s350.

20. Verma RB, Sherman O. Athletic stress fractures: part I. History, epidemiology, physiology, risk factors, radiography, diagnosis, and treatment. Am J Orthop (Belle Mead NJ). 2001;30(11):798-806.

21. Clement DB, Ammann W, Taunton JE, et al. Exercise-induced stress injuries to the femur. Int J Sports Med. 1993;14(6):347-352.

22. Lappe J, Davies K, Recker R, Heaney R. Quantitative ultrasound: use in screening for susceptibility to stress fractures in female army recruits. J Bone Miner Res. 2005;20(4):571-578.

23. Ohta-Fukushima M, Mutoh Y, Takasugi S, Iwata H, Ishii S. Characteristics of stress fractures in young athletes under 20 years. J Sports Med Phys Fitness. 2002;42(2):198-206.

24. Kaeding CC, Najarian RG. Stress fractures: classification and management. Phys Sportsmed. 2010;38(3):45-54.

25. Miller T, Kaeding CC, Flanigan D. The classification systems of stress fractures: a systematic review. Phys Sportsmed. 2011;39(1):93-100.

26. Spitz DJ, Newberg AH. Imaging of stress fractures in the athlete. Radiol Clin North Am. 2002;40(2):313-331.

27. Lee JK, Yao L. Stress fractures: MR imaging. Radiology. 1988;169(1): 217-220. 
28. Wall J, Feller JF. Imaging of stress fractures in runners. Clin Sports Med. 2006;25(4):781-802.

29. Shiraishi M, Mizuta H, Kubota K, Sakuma K, Takagi K. Stress fracture of the proximal phalanx of the great toe. Foot Ankle. 1993;14(1): 28-34.

30. Ashman CJ, Klecker RJ, Yu JS. Forefoot pain involving the metatarsal region: differential diagnosis with $\mathrm{MR}$ imaging. Radiographics. 2001;21(6):1425-1440.

31. Karasick D, Schweitzer ME. Disorders of the hallux sesamoid complex: MR features. Skeletal Radiol. 1998;27(8):411-418.

32. Hockenbury RT. Forefoot problems in athletes. Med Sci Sports Exerc. 1999;31(Suppl 7):S448-S458.

33. Weist R, Eils E, Rosenbaum D. The influence of muscle fatigue on electromyogram and plantar pressure patterns as an explanation for the incidence of metatarsal stress fractures. Am J Sports Med. 2004;32(8): 1893-1898.

34. Saxena A, Krisdakumtorn T, Erickson S. Proximal fourth metatarsal injuries in athletes: similarity to proximal fifth metatarsal injury. Foot Ankle Int. 2001;22(7):603-608.

35. Kavanaugh JH, Brower TD, Mann RV. The Jones fracture revisited. J Bone Joint Surg Am. 1978;60(6):776-782.

36. Portland G, Kelikian A, Kodros S. Acute surgical management of Jones' fractures. Foot Ankle Int. 2003;24(11):829-833.

37. Vertullo CJ, Glisson RR, Nunley JA. Torsional strains in the proximal fifth metatarsal: implications for Jones and stress fracture management. Foot Ankle Int. 2004;25(9):650-656.

38. Csizy M, Babst R, Fridrich KS. ["Bone tumor" diagnostic error in stress fracture of the medial tibial plateau]. Unfallchirurg. 2000;103(11): 993-995. German.

39. Battaglia H, Simmen HP, Meier W. [Stress fractures of the cuboid bone: an easy to treat rarity]. Swiss Surg. 2002;8(1):3-6. German.

40. Beaman DN, Roeser WM, Holmes JR, Saltzman CL. Cuboid stress fractures: a report of two cases. Foot Ankle. 1993;14(9):525-528.

41. Black KP, Ehlert KJ. A stress fracture of the lateral process of the talus in a runner. A case report. J Bone Joint Surg Am. 1994;76(3): 441-443.

42. Golano P, Fariñas O, Sáenz I. The anatomy of the navicular and periarticular structures. Foot Ankle Clin. 2004;9(1):1-23.

43. Torg JS, Moyer J, Gaughan JP, Boden BP. Management of tarsal navicular stress fractures: conservative versus surgical treatment: a meta-analysis. Am J Sports Med. 2010;38(5):1048-1053.

44. Batt ME, Ugalde V, Anderson MW, Shelton DK. A prospective controlled study of diagnostic imaging for acute shin splints. Med Sci Sports Exerc. 1998;30(11):1564-1571.

45. Brewer RB, Gregory AJ. Chronic lower leg pain in athletes: a guide for the differential diagnosis, evaluation, and treatment. Sports Health. 2012;4(2):121-127.

46. Gaeta M, Minutoli F, Scribano E, et al. CT and MR imaging findings in athletes with early tibial stress injuries: comparison with bone scintigraphy findings and emphasis on cortical abnormalities. Radiology. 2005;235(2):553-561.

47. Bennell K, Crossley K, Jayarajan J, et al. Ground reaction forces and bone parameters in females with tibial stress fracture. Med Sci Sports Exerc. 2004;36(3):397-404.

48. Boden BP, Osbahr DC, Jimenez C. Low-risk stress fractures. Am J Sports Med. 2001;29(1):100-111.

49. Chang PS, Harris RM. Intramedullary nailing for chronic tibial stress fractures. A review of five cases. Am J Sports Med. 1996;24(5): 688-692.

50. Rettig AC, Shelbourne KD, McCarroll JR, Bisesi M, Watts J. The natural history and treatment of delayed union stress fractures of the anterior cortex of the tibia. Am J Sports Med. 1988;16(3): $250-255$.

51. Stewart GW, Brunet ME, Manning MR, Davis FA. Treatment of stress fractures in athletes with intravenous pamidronate. Clin J Sport Med. 2005;15(2):92-94

52. Iwaya T, Takatori Y. Lateral longitudinal stress fracture of the patella: report of three cases. J Pediatr Orthop. 1985;5(1):73-75.
53. Ogden JA, McCarthy Sm, Jokl P. The painful bipartite patella. J Pediatr Orthop. 1982;2(3):263-269.

54. Scott MP, Finnoff JT, Davis BA. Femoral neck stress fracture presenting as gluteal pain in a marathon runner: case report. Arch Phys Med Rehabil. 1999;80(2):236-238.

55. Crockett HC, Wright JM, Madsen MW, Bates JE, Potter HG, Warren RF. Sacral stress fracture in an elite college basketball player after the use of a jumping machine. AM J Sports Med. 1999;27(4):526-528.

56. Johansson C, Ekenman I, Törnkvist H, Eriksson E. Stress fractures of the femoral neck in athletes. The consequence of a delay in diagnosis. Am J Sports Med. 1990;18(5):524-528.

57. Visuri T. Stress osteopathy of the femoral head. 10 military recruits followed for 5-11 years. Acta Orthop Scand. 1997;68(2):138-141.

58. Clough TM. Femoral neck stress fracture: the importance of clinical suspicion and early review. Br J Sports Med. 2002;36(4):308-309.

59. Hershman EB, Lombardo J, Bergfeld JA. Femoral shaft stress fractures in athletes. Clin Sports Med. 1990;9(1):111-119.

60. Egol KA, Koval KJ, Kummer F, Frankel VH. Stress fracture of the femoral neck. Clin Orthop Relat Res. 1998;348:72-78.

61. Thorne DA, Datz FL. Pelvis stress fracture in female runners. Clin Nucl Med. 1986;11(12):828-829.

62. O'Brien T, Wilcox N, Kersch T. Refractory pelvic stress fracture in a female long-distance runner. Am J Orthop (Belle Mead NJ). 1995;24(9):710-713.

63. Noakes TD, Smith JA, Lindenberg G, Wills CE. Pelvic stress fractures in long distance runners. Am J Sports Med. 1985;13(2):120-123.

64. Hill PF, Chatterji S, Chambers D, Keeling JD. Stress fracture of the pubic ramus in female recruits. J Bone Joint Surg Br. 1996;78(3): 383-386.

65. Ahovuo JA, Kiuru MJ, Kinnunen JJ, Haapamaki V, Pihlajamaki HK. MR imaging of fatigue stress injuries to bones: intra- and interobserver agreement. Magn Reson Imaging. 2002;20(5):401-406.

66. Brunet ME, Cook SD, Brinker MR, Dickinson JA. A survey of running injuries in 1505 competitive and recreational runners. J Sports Med Phys Fitness. 1990;30(3):307-315.

67. Friedl KE, Nuovo JA, Patience TH, Dettori JR. Factors associated with stress fracture in young army women: indications for further research. Mil Med. 1992;157(7):334-338.

68. Gardner LI, Dziados JE, Jones BH, et al. Prevention of lower extremity stress fractures: a controlled trial of a shock absorbent insole. Am J Public Health. 1988;78(12):1563-1567.

69. Myburgh KH, Hutchins J, Fataar AB, Hough SF, Noakes TD. Low bone density is an etiologic factor for stress fractures in athletes. Ann Intern Med. 1990;113(10):754-759.

70. Shaffer RA, Brodine SK, Almeida SA, Williams KM, Ronaghy S. Use of simple measures of physical activity to predict stress fractures in young men undergoing a rigorous physical training program. Am J Epidemiol. 1999;149(3):236-242.

71. Lloyd T, Triantafyllou SJ, Baker ER, et al. Women athletes with menstrual irregularity have increased musculoskeletal injuries. Med Sci Sports Exerc. 1986;18(4):374-379.

72. Barrow GW, Saha S. Menstrual irregularity and stress fractures in collegiate female distance runners. Am J Sports Med. 1988;16(3): 209-216.

73. Altarac M, Gardner JW, Popovich RM, Potter R, Knapik JJ, Jones BH. Cigarette smoking and exercise-related injuries among young men and women. Am J Prev Med. 2000;18(Suppl 3):96-102.

74. Jones BH, Shaffer RA, Snedecor MR. Chapter 6. Injuries treated in outpatient clinics: surverys and research data. Mil Med. 1999; 164(Suppl 8):1-89.

75. Reynolds KL, Heckel HA, Witt CE, et al. Cigarette smoking, physical fitness, and injuries in infantry soldiers. Am J Prev Med. 1994;10(3): $145-150$.

76. Andrish JT. The leg. In: Delee JC, Drez D, editors. Orthopaedic Sports Medicine: Principle and Practice. Philadelphia: WB Saunders; 1994.

77. Ziltener JL, Leal S, Fournier PE. Non-steroidal anti-inflammatory drugs for athletes: an update. Ann Phys Rehabil Med. 2010;53(4):278-282. 
78. Ardent E, Agel J, Heikes C, Griffiths H. Stress injuries to bone in college athletes: a retrospective review of experience at a single institution. Am J Sports Med. 2003;31(6):959-968.

79. Hoffman MD, Donaghe HE. Physiological responses to body weight supported treadmill exercise in healthy adults. Arch Phys Med Rehabil. 2011;92(6):960-966.

80. Hodges PW, Richarsdon CA. Inefficient muscular stabilization of the lumbar spine associated with low back pain. A motor control evaluation of transversus abdominis. Spine (Phila Pa 1976). 1996;21(22): 2640-2650.

81. Ireland ML, Willson JD, Ballantyne BT, Davis IM. Hip strength in females with and without patellofemoral pain. J Orthop Sports Phys Ther. 2003;33(11):671-676

82. Jung AP. The impact of resistance training on distance running performance. Sports Med. 2003;33(7):539-552.

83. Knobloch K, Schreibmueller L, Jagodzinski M, Zeichen J, Krettek C. Rapid rehabilitation programme following sacral stress fracture in a long-distance running female athlete. Arch Orthop Trauma Surg. 2007;127(9):809-813.

84. Niemuth PE, Johnson RJ, Myers MJ, Thieman TJ. Hip muscle weakness and overuse injuries in recreational runners. Clin J Sport Med. 2005;15(1):14-21.

85. Pohl MB, Mullineaux DR, Milner CE, Hamill J, Davis IS. Biomechanical predictors of retrospective tibial stress fractures in runners. $J$ Biomech. 2008;41(6):1160-1165.

86. Crowell HP, Davis IS. Gate retraining to reduce lower extremity loading in runners. Clin Biomech (Bristol, Avon). 2001;26(1):78-83.

87. Crowell HP, Milner CE, Hamill J, Davis IS. Reducing impact loading during running with the use of real-time visual feedback. J Orthop Sports Phys Ther. 2010;40(4):206-213.

88. Zadpoor AA, Nikooyan AA. The relationship between lower-extremity stress fractures and the ground reaction force: a systematic review. Clin Biomech (Bristol, Avon). 2011;26(1):23-28.

89. American College of Sports Medicine. American College of Sports Medicine position stand. Progression models in resistance training for healthy adults. Med Sci Sports Exerc. 2009;41(3):687-708.

90. Harmon KG. Lower extremity stress fractures. Clin J Sport Med. 2003;13(6):358-364.

91. Beck BR, Matheson GO, Bergman G, et al. Do capacitively coupled electric fields accelerate tibial stress fracture healing? A randomized controlled trial. Am J Sports Med. 2008;36(3):545-553.

92. Dobrindt O, Hoffmeyer B, Ruf J, et al. Estimation of return-to-sportstime for athletes with stress fracture - an approach combining risk level of fracture site with severity based on imaging. BMC Musculoskelet Disord. 2012;13:139.

93. Dugan SA, Bhat KP. Biomechanics and analysis of running gait. Phys Med Rehabil Clin N Am. 2005;16(3):603-621.

94. Johnson AW, Weiss CB, Stento K, Wheeler DL. Stress fractures of the sacrum. An atypical cause of low back pain in the female athlete. Am J Sports Med. 2001;29(4):498-508.

95. Koplan JP, Powell KE, Sikes RK, Shirley RW, Campbell CC. An epidemiologic study of the benefits and risks of running. JAMA. 1982;248(23):3118-3121.

96. Macera CA, Pate RR, Powell KE, Jackson KL, Kendrick JS, Craven TE. Predicting lower-extremity injuries among habitual runners. Arch Intern Med. 1989;149(11):2565-2568.
97. Marti B, Vader JP, Minder CE, Abelin T. On the epidemiology of running injuries. The 1984 Bern Grand-Prix study. Am J Sports Med. 1988;16(3):285-294.

98. Zahger D, Abramovitz A, Zelikovsky L, Israel O, Israel P. Stress fractures in female soldiers: an epidemiological investigation of an outbreak. Mil Med. 1988;153(9):448-450.

99. Rome K, Handoll HH, Ashford RL. Interventions for preventing and treating stress fractures and stress reactions of bone of the lower limbs in young adults. J Orthop Sports Phys Ther. 2007;37: $40-47$.

100. Tenforde AS, Watanabe LM, Moreno TJ, Fredericson M. Use of an antigravity treadmill for rehabilitation of a pelvic stress injury. PM R. 2012;4(8):629-631.

101. Chung M, Balk EM, Brendel M, et al. Vitamin D and Calcium; a Systematic Review of Health Outcomes. Evidence report no 183. AHRQ publication no 09-E015. Rockville, MD: Agency for Healthcare Research and Quality; 2009. Available from: http:/www.ahrq gov/downloads/pub/evidence/pdf/vitadcal/vitadcal.pdf. Accessed January 19, 2015.

102. Nieves JW, Melsop K, Curtis M, et al. Nutritional factors that influence change in bone density and stress fracture risk among young female cross-country runners. PM R. 2010;2(8):740-750.

103. Heckman JD, Ryaby JP, McCabe J, Frey JJ, Kilcoyne RF. Acceleration of tibial fracture-healing by non-invasive, low-intensity pulsed ultrasound. J Bone Joint Surg Am. 1994;76(1):26-34.

104. Milgrom C, Finestone A, Novack V, et al. The effect of prophylactic treatment with risedronate on stress fracture incidence among infantry recruits. Bone. 2004;35(2):418-424.

105. Wentz L, Liu PY, Ilich JZ, Haymes EM. Dietary and training predictors of stress fractures in female runners. Int J Sport Nutr Exerc Metab 2012;22(5):374-382.

106. Banal F, Gandjbakhch F, Foltz V, et al. Sensitivity and specificity of ultrasonography in early diagnosis of metatarsal bone stress fractures: a pilot study of 37 patients. J Rheumatol. 2009;36(8) $1715-1719$.

107. Hoch AZ, Peper M, Akuthota V. Stress fracture and knee injuries in runners. Phys Med Rehab Clin NAm. 2005;16(3):749-777.

108. Cowan DN, Bedno SA, Urban N, Lee DS, Niebuhr DW. Step test performance and risk of stress fractures among female army trainees. Am J Prev Med. 2012;42(6):620-624.

109. Shelbourne KD, Fisher DA, Rettig AC, McCarroll JR. Stress fractures of the medial malleolus. Am J Sports Med. 1988;16(1) 60-63.

110. Young AJ, McAllister DR. Evaluation and treatment of tibial stress fractures. Clin Sports Med. 2006;25(1):117-128, x.

111. Ivkovic A, Bojanic I, Pecina M. Stress fractures of the femoral shaft in athletes: a new treatment algorithm. Br J Sports Med. 2006;40(6) 518-520; discussion 520.

112. Anderson MW, Kaplan PA, Dussault RG. Adductor insertion avulsion syndrome (thigh splints): spectrum of MR imaging features. AJR Am J Roentgenol. 2001;177(3):673-675

Open Access Journal of Sports Medicine

\section{Publish your work in this journal}

Open Access Journal of Sports Medicine is an international, peer-reviewed, open access journal publishing original research, reports, reviews and commentaries on all areas of sports medicine. The manuscript management system is completely online and includes a very quick and fair peer-review system. 